\title{
HUKUM PEGAJUAN KEPAILITAN TERHADAP PENGUSAHA OLEH PEKERJA KARENA HAK PEKERJA YANG TIDAK DIBAYAR
}

\author{
Nikmah Dalimunthe \\ UIN Sumatera Utara Medan \\ E-mail: nikmahdalimunthe5@gmail.com
}

\begin{tabular}{|c|c|c|}
\hline Received & Revised & Accepted \\
\hline 4 July 2021 & 2 Agustus 2021 & 20 September 2021 \\
\hline
\end{tabular}

\section{LAW OF APPLICATION FOR BANKRUPTCY AGAINST ENTREPRENEURS BY WORKERS FOR UNPAID WORKERS' RIGHTS}

\begin{abstract}
This study aims to analyze industrial relations in Indonesia regarding the tendency of workers to use bankruptcy legal instruments by filing for bankruptcy against the company for the rights of workers who are not paid (wages and severance pay) by the company. In the usual settlement flow, workers will take legal action through the settlement of industrial relations disputes with a pure civil law character in defending their rights which are not paid for by the company. However, legal remedies through the settlement of industrial relations disputes are often ineffective due to various reasons and backgrounds. In this study, it was found that there was an alternative use of legal remedies by workers in defending their rights which were not paid for by the employer by filing for bankruptcy against the company and this is an alternative legal remedy that is more effective than taking legal remedies to settle industrial relations disputes. Legal efforts to use bankruptcy by workers to claim their rights that are not paid for by the company are possible in bankruptcy law and labor law in Indonesia.
\end{abstract}

Keywords: filing for bankruptcy, workers, employers, and normative rights.

\begin{abstract}
Absrak
Penelitian ini bertujuan untuk menganalisis hubungan industri di Indonesia mengenai kecenderungan pekerja untuk menggunakan instrumen hukum kepailitan dengan mengajukan kepailitan terhadap perusahaan atas hak-hak pekerja yang tidak dibayar (upah dan pesangon) oleh perusahaan. Pada alur penyelesaian yang lazim adalah pekerja akan menempuh upaya hukum melalui penyelesaian perselisihan hubungan industrial yang berkarakter hukum perdata murni dalam mempertahankan hak-haknya yang tidak dibayar oleh perusahaan. Namun upaya hukum melalui penyelesaian perselisihan hubungan industrial tersebut seringkali tidak efektif karena berbagai sebab dan latar belakang. Dalam
\end{abstract}


penelitian ini ditemukan adanya penggunaan altenatif upaya hukum oleh pekerja dalam mempertahankan hak-haknya yang tidak dibayar oleh pengusaha dengan mengajukan kepailitan terhadap perusahaan dan hal ini merupakan alternatif upaya hukum yang lebih efektif daripada menempuh upaya hukum penyelesaian perselisihan hubungan industrial. Upaya hukum penggunaan kepailitan oleh pekerja untuk menagih hak-haknya yang tidak dibayar perusahaan, dimungkinkan dalam hukum kepailitan dan hukum perburuhan di Indonesia.

Kata kunci: pengajuan kepailitan, pekerja, pengusaha, dan hak normatif.

\section{Pendahuluan}

Hubungan kerja dalam hubungan industrial merupakan perikatan hukum antara dua pihak, yaitu pengusaha dan pekerja. Hubungan hukum yang terjadi antara pengusaha yang menjalankan perusahaan dengan pekerja tersebut merupakan hubungan hukum yang khuusus dan unik yang diatur dalam hukum perburuhan. Hal ini juga berlaku di hukum perburuhan Indonesia. Adapun kekhususan dan keunikan hubungan hukum antara pengusaha dengan pekerja adalah karena latar belakang ekonomi yang berbeda dimana pengusaha memiliki posisi ekonomi yang kuat sebagai pemilik perusahaan dibanding dengan pekerja yang berlatar belakang ekonomi tidak mampu serta sangat membutuhkan pekerjaan tersebut. ${ }^{1}$

Hubungan hukum industrial tersebut menjadi semakin timpang oleh karena berlaku hukum penawaran dan permintaan dimana pekerja yang membutuhkan pekerjaan jauh lebih banyak daripada lowongan pekerjaan yang tersedia ${ }^{2}$. Adapun kondisi hubungan industrial yang timpang tersebut, diperlukan perlindungan hukum terhadap pekerja atas kekuasaan pengusaha yang sangat kuat. Perlindungan hukum merupakan suatu bentuk perlindungan yang diberikan oleh negara kepada subyek hukum (orang maupun badan hukum) yang sesuai dengan norma hukum, yang mencakup perlindungan hukum preventif maupun perlindungan hukum represif, baik yang dinormakan secara tertulis dalam suatu peraturan perundang -undangan maupun dalam bentuk norma yang tidak tertulis yang ditujukan dalam kaitan dengan penegakan hukum³.

Perlindungan hukum ini dimaksudkan untuk memberikan keseimbangan hubungan hukum antara pengusaha dengan pekerja .Iman Soepomo mengatakan bahwa perlindungan terhadap pekerja mencakup tiga jenis perlindungan, yaitu: perlindungan secara ekonomis, perlindungan dalam konteks sosial, serta perlindungan secara teknis (keselamatan dan kesehatan kerja). Tanpa ada perlindungan hukum tersebut, terjadi kecenderangan pengusaha untuk bertindak sewenang-wenang akan terus meningkat.

Meskipun telah diberikan proteksi hukum dalam berbagai ketentuan peraturan perundang-undangan, namun tetap saja sering terjadi pelanggaran

\footnotetext{
${ }^{1}$ M. Hadi Shubhan, Fenomena Hukum Pengajuan Kepailitan Terhadap Pengusaha Oleh Pekerja Karena Hak Pekerja Yang Tidak Dibayar Pengusaha, Jurnal Hukum \& Pembangunan, 50 No. 2 (2020): 519-539

2 Ali Miftakhu Rosyad, "Urgensi Inovasi Pembelajaran Islam Dalam PAI," Al-Afkar, Journal for Islamic Studies 2, no. 1 (2019): 64-86, https://doi.org/10.5281/zenodo.3553865.

${ }^{3}$ Adi Wibowo, "Tinjauan Hukum Islam Terhadap Praktik Pinjammeminjam Uang Di Desa Nglorog Kec. Sragen Kab. Sragen," Skripsi--UIN Sunan Kalijaga, Yogyakarta, 2013.
} 
terhadap hak-hak normatif pekerja yang dilakukan oleh pengusaha dengan berbagai macam sebab dan latar belakang. Ketika terjadi pelanggaran terhadap hak pekerja tersebut, maka oleh negara disediakan jalur upaya hukum yang dapat dilakukan oleh pekerja. Upaya hukum tersebut dapat dilakukan pada jalur hukum administrasi negara, dapat pula dilakukan melalui jalur keperdataan, serta dapat pula menggunakan jalur pidana ${ }^{4}$.

Upaya hukum yang bisa dilakukan oleh pekerja, seperti jalur hukum administrasi negara merupakan jalur hukum publik, dimana negara banyak terlibat dalam penyelesaian perselisihan ini. Negara hadir melalui, antara lain, pegawai pengawas ketenagakerjaan. Pekerja dapat mengadukan permasalahannya kepada pegawai pengawas ketenagakerjaan baik ditingkat daerah maupun di tingkat pusat. Pengawas ketenagakerjaan bertugas memastikan hubungan industrial dijalankan dengan mematuhi semua ketentuan peraturan perundang-undangan sebagai norma kerja heteronom dan ketentuan internal perusahaan sebagai ketentuan otonom. Apabila ada pelanggaran yang dilakukan oleh pengusaha, maka pengawas ketenagakerjaan akan memberikan sanksi administratif. Sanksi administratif dapat berupa surat teguran, tindakan paksa tertentu, maupun penghentian pelayanan publik 5 .

Upaya hukum yang dilakukan oleh pekerja melalui jalur kepidanaan juga merupakan jalur hukum publik, yang terdapat keterlibatan negara dalam proses penyelesaian perselisihan tersebut. Negara juga harus hadir melalui penyidik pegawai negeri sipil (PPNS) dan kepolisian. Penggunaan jalur pidana ini digunakan dalam hal adanya pelanggaran hak-hak pekerja yang oleh undang-undang diancam dengan suatu norma saknsi pidana atas pelanggaran tersebut. Hal ini karena terdapat beberapa ketentuan yang apabila dilanggar maka diancam dengan sanksi pidana, seperti pelanggaran pembayaran upah dibawah minimum, tidak mengikutsertakan pekerja dalam jaminan sosial, dan pelanggaran berupa union busting (pemberangusan serikat pekerja). Adapun jenis sanksi pidana perburuhan berupa pidana penjara dan/atau denda ${ }^{6}$.

Upaya hukum lain yang digunakan pekerja untuk mempertahankan hak-hak normatif yang dilanggar oleh pengusaha adalah melalui upaya hukum keperdataan. Upaya hukum keperdataan yang disediakan khusus oleh negara adalah melalui suatu Penyelesaian Perselisihan Hubungan Industrial (PPHI). Negara membuat hukum materiil khusus, hukum acara khusus, dan pengadilan khusus terkait perselisihan hubungan industrial. Untuk penyelesaian perselisihan hubungan industrial dibagi empat macam/bentuk perselisihan, yaitu, perselisihan hak karena pelanggaran atas hak yang seharusnya diberikan, perselisihan kepentingan yang terkait dengan syarat-syarat kerja, perselisihan pemutusan hubungan kerja yang

\footnotetext{
${ }^{4}$ Zainul Arifin and Irsan Irsan, "Korupsi Perizinan Dalam Perjalanan Otonomi Daerah Di Indonesia," Lex Librum: Jurnal Ilmu Hukum 5, no. 2 (2019): 887-96.

${ }^{5}$ Ali Miftakhu Rosyad and Muhammad Anas Maarif, "PARADIGMA PENDIDIKAN DEMOKRASI DAN PENDIDIKAN ISLAM DALAM MENGHADAPI TANTANGAN GLOBALISASI DI INDONESIA," Nazhruna: Jurnal Pendidikan Islam 3, no. 1 (2020): 75-99.

${ }^{6}$ Hasan Baharun, Adi Wibowo, and Siti Nur Hasanah, "Kepemimpinan Perempuan Dalam Menciptakan Sekolah Ramah Anak," Quality 9, no. 1 (2021): 87-102.
} 
terkait dengan alasan dan pemberian kompensasi PHK, serta perselisihan antar serikat pekerja/serikat buruh dengan serikat pekerja/serikat buruh lain dalam satu badan usaha perusahaan ${ }^{7}$.

Upaya hukum melalui penyelesaian perselisihan hubungan industrial (PPHI) banyak menemukan kendala dalam pelaksanaannya. Kendala yang yang ditemui antara lain proses yang panjang dari awal sampai akhir putusan di pengadilan dan sulitnya melakukan eksekusi putusan pengadilan. Berdasarkan latar belakang tersebut, maka masalah hukum yang akan diteliti dalam penelitian ini adalah apakah kendala yang ditemui pekerja dalam mempertahankan hak-haknya melalui jalur penyelesaian perselisihan hubungan industrial, apakan pekerja dapat menempuh upaya hukum melalui permohonan kepailitan terhadap perusahaan sebagai alternatif upaya hukum lain serta bagaimana praktik di pengadilan terhadap upaya hukum permohonan pailit terhadap perusahaan oleh pekerja yang dilanggar hak-hak normatifnya ${ }^{8}$. Untuk menjawab isu hukum tersebut maka akan diteliti adalah karakteristik hukum perburuhan Indonesia, karakteristik hukum kepailitan di Indonesia, kajian teoritik, normatif, dan praktik pengadilan atas penggunaan upaya hukum kepailitan oleh buruh terhadap pengusaha atas dasar tidak dibayarnya hak-hak pekerja oleh perusahaan.

\section{Metode Penelitian}

Jenis Penelitian dalam penulisan ini adalah penelitian pustaka (library research) yaitu dengan mencari data atau informasi riset melalui membaca jurnal ilmiah, buku-buku referensi, laporan keuangan yang di publikasi dan bahan-bahan publikasi yang tersedia di perpustakaan sebagai pendukung dalam penulisan ini. Penelitian ini menggunakan model penelitian deskriptif bertujuan membuat deskripsi yang akurat, faktual, dan sistematis pada fakta tertentu. Penelitian ini menggunakan data kualitatif, yaitu data yang berbentuk kata, kalimat atau skema dan gambar. Sumber data penelitian ini dari data sekunder, yaitu sumber datanya tidak langsung melalui studi kepustakaan, catatan dan buku-buku yang ada.

Dalam penelitian ini penulis mengumpulkan data atau informasi dengan cara membaca atau mengutip, dan menyusunnya berdasarkan data-data yang telah diperoleh yang berasal dari data primer dan data sekunder. Dalam penelitian ini yang diperoleh dari data sekunder. Data sekunder adalah data yang diperoleh dari catatan, buku dan majalah , dan lain sebagainya. Beberapa sumber sekunder yang peniliti peroleh adalah data-data dari internet, jurnal, dan buku-buku sebagai bahan pelengkap dalam penelitan ini

\footnotetext{
${ }^{7}$ Achmad Fawaid, Zamroni Zamroni, and Hasan Baharun, "Contesting Sacred Architecture: Politics of 'Nation-State'in the Battles of Mosques in Java," QIJIS (Qudus International Journal of Islamic Studies) 7, no. 1 (2019): 129-72.

${ }^{8}$ Fikri, "Transformation the Value of Al-Islah in the Diversity of Conflict: Epistemology Islamic Law in the Qur'an," Al-Risalah: Forum Kajian Hukum Dan Sosial Kemasyarakatan 16, no. 2 (2016): 201-16.
} 


\section{Hasil dan Pembahasan \\ Pengertian Pailit}

Pailit dalam kamus besar bahasa Indonesia diartikan sebagai keadaan yang merugi, bangkrut.Sedangkan dalam kamus hukum ekonomi menyebutkan bahwa, liquidation, likuidasi: pembubaran perusahaan diikuiti dengan proses penjualan harta perusahaan, penagihan piutang, pelunasan utang, serta penyelesaian sisa harta atau utang antara pemegang saham ${ }^{9}$.

Beberapa definisi tentang kepailitan telah di terangkan didalam jurnal Penerapan Ketentuan Kepailitan Pada Bank Yang Bermasalah yang ditulis oleh Ari Purwadi antara lain: Freed B.G Tumbunan dalam tulisannya yang berjudul Pokok- PokokUndang-Undang Tentang Kepailitan sebagaimana diubah oleh Perpu No. 1 Tahun 1998 disebutkan bahwa "Kepailitan adalah sita umum yang mencakup seluruh kekayaan debitur untuk kepentingan semua krediturnya. Tujuan kepailitan adalah pembagian kekayaan debitur oleh kurator kepada semua kreditur dengan memperhatikan hak-hak mereka masing-masing" .

Kepailitan merupakan suatu proses dimana seorang debitur yang mempunyai kesulitan keuangan untuk membayar utangnya dinyatakan pailit oleh pengadilan, dalam hal ini adalah pengadilan niaga, dikarenakan debitur tersebut tidak dapat membayar utangnya, harta debitur dapat dibagikan kepada para kreditur sesuai dengan peraturan perundangan yang berlaku.

Pasal 1 angka (1) Undang-Undang Nomor 37 Tahun 2004 menyatakan bahwa yang dimaksud dengan kepailitan adalah sita umum atas semua kekayaan Debitor Pailit yang pengurusan dan pemberasannya dilakukan oleh Kurator dibawah pengawasan Hakim Pengawas sebagaimana diatur dalam Undang-Undang ini.

Kepailitan adalah sita umum yang mencakup seluruh kekayaan debitur untuk kepentingan semua krediturnya. Tujuan kepailitan adalah pembagian kekayaan debitur oleh kurator kepada semua kreditur dengan memperhatikan hak-hak mereka masing- masing".

\section{Pihak-Pihak Yang Dapat Mengajukan Kepailitan}

1) Pihak Pemohon Pailit

Menurut pasal 2 undang-undang kepailitan Nomor 37 Tahun 2004 maka yang dapat menjadi pemohon dalam suatu perkara pailit adalah salah-satu pihak berikut ini:
a. Pihak Debitur itu sendiri
b. Salah-satu atau lebih dari pihak Kreditur
c. Pihak kejaksaan jika menyangkut dengan kepentingan umum
d. Pihak Bank Indonesia jika debiturnya adalah suatu bank

\footnotetext{
${ }^{9}$ Rahmani Timorita Yulianti, "Transparansi Anggaran: Suatu Upaya Efisiensi Dan Antisipasi Korupsi Di Indonesia," La_Riba: Jurnal Ekonomi Islam 4, no. 2 (2010): 239-50.

${ }^{10}$ Hasan Baharun et al., "MODERNISASI PENDIDIKAN DI PONDOK PESANTREN: Studi Tentang Pemanfaatan Sistem Aplikasi Pedatren Dalam Meningkatkan Mutu Layanan Pondok Pesantren," Al-Tarbawi Al-Haditsah: Jurnal Pendidikan Islam 6, no. 1 (2021): 1-22.

${ }^{11}$ Ali Miftakhu Rosad, "IMPLEMENTASI PENDIDIKAN KARAKTER MELALUI MANAGEMEN SEKOLAH," Tarbawi: Jurnal Keilmuan Manajemen Pendidikan 5, no. 02 (2019): 173-90.
} 
e. Pihak Badan Pengawas Pasar Modal jika debiturnya suatu perusahaan efek. Yang dimaksud dengan perusahaan efek, bursa efek, lembaga kliring dan penjaminan, serta lembaga penyimpanan dan penyelesaian

f. Pihak Menteri Keuangan jika debiturnya perusahaan asuransi, reasuransi, dana pensiun, BUMN yang bergerak di bidang kepentingan publik.

2) Pihak Debitur Pailit

Pihak debitur pailit adalah pihak yang memohon atau dimohonkan pailit ke pengadilan yang berwenang. Yang dapat menjadi debitur pailit adalah debitur yang mempunyai dua atau lebih kreditur dan tidak membayar sedikitnya satu hutang yang telah jatuh waktu dan dapat ditagih ${ }^{12}$.

3) Hakim Niaga

Perkara kepailitan pada tingkat pertama diperiksa oleh hakim majelis, tidak boleh hakim tunggal (pasal 301 ayat 1). Hanya untuk perkara perniagaan lainnya yakni yang bukan perkara kepailitan untuk tingkat pengadilan pertama yang boleh diperiksa oleh hakim tunggal dengan penetapan ketua Mahkamah Agung (pasal 3o1ayat 2). Hakim Majelis tersebut merupakan hakim-hakim pada pengadilan niaga, yakni hakim-hakim Pengadilan Negeri yang telah diangkat menjadi hakim pengadilan niaga berdasarkan keputusan ketua Mahkamah Agung (pasal 301 ayat 2).

\section{Keputusan Pailit dan Akibat Hukumnya}

Dalam pasal 21 kepailitan meliputi seluruh kekayaan debitor pada saat putusan pernyataan pailit diucapkan serta segala sesuatu yang diperoleh selama kepaillitan.Namun, ketentuan sebagaimana dalam pasal 21 di atas tidak berlaku terhadap barang-barang sebagai berikut:

1 Benda, termasuk hewan yang benar-benar dibutuhkan oleh debitor sehubungandengan pekerjaannya, perlengkapannya, alat- alat medis yang dipergunakan untuk kesehatan, tempat tidur dan perlengkapannya yang digunakan oleh debitor dan keluarganya.

2. Segala sesuatu yang diperoleh debitor dari pekerjaannya sendiri sebagai penggajian dari suatu jabatan atau jasa sebagai upah, pensiun, uang tunggu, atau uang tunjangan yang ditentukan oleh hakim pengawas ${ }^{13}$.

3. Uang yang diberikan kepada debitor untuk memenuhi suatu kewajiban member nafkah menurut undang-undang.

Putusan pernyataan pailit berakibat bahwa segala penetapan pelaksanaan pengadilan terhadap setiap bagian dari kekayaan debitor yang telah dimulai sebelum kepailitan harus dihentikan seketika dan sejak itu tidak ada suatu putusan yang dapat dilaksanakan termasuk atau juga dengan menyandera debitor.

\footnotetext{
${ }^{12}$ Mohammad Daud Ali, Sistem Ekonomi Islam: Zakat Dan Wakaf (Penerbit Universitas Indonesia, 1988).

${ }^{13}$ Nopirin Nopirin, "Pengantar Ilmu Ekonomi Makro Dan Mikro," Yogyakarta: BPFE UGM, 2000.
} 


\section{Akibat Hukum Kepailitan}

Saat Pengadilan Niaga memutuskan pailit suatu debitor maka putusan tersebut akan menimbulkan akibat hukum. Menurut M. Hadi Shubban (2008: 162), akibat yuridis dari putusan pailit terhadap harta kekayaan debitur maupun terhadap debitor adalah sebagai berikut:

a. Putusan pailit dapat dijalankan terlebih dahulu (serta-merta) meskipun terhadap putusan tersebut masih dilakukan upaya hukum lebih lanjut;

b. Harta kekayaan debitor yang masuk harta pailit merupakan sita umum (publicattachment, gerechtelijk beslag) beserta apa yang diperoleh selama kepailitan.

c. Debitor kehilangan wewenang dalam harta kekayaan untuk mengurus dan melakukan perbuatan kepemilikan ${ }^{14}$.

d. Segala perbuatan yang terbit setelah putusan pailit tidak dapat dibayar dari harta pailit. Imran Naning, menyatakan secara umum akibat pernyataan pailit adalah sebagai berikut :

1. Kekayaan debitor pailit yang masuk harta pailit merupakan sita umum atas harta pailit yang dinyatakan pailit menurut pasal 21 UU No. 37 Tahun 2004 tentang Kepailitan dan PKPU, harta pailit meliputi seluruh kekayaan debitor pada waktu putusan pailit diucapkan serta segala kekayaam yang diperoleh debitur pailit selama kepailitan.

2. Kepailitan semata -mata hanya mengenai harta pailit dan tidak mengenai diri pribadi debitor pailit. Misalnya seseorang dapat melangsungkan pernikahan meskipun telah dinyatakan pailit.

3. Debitor pailit demi hokum kehilangan hak untuk mengurus dan menguasai kekayaannya yang termasuk harta pailit sejak hari putusan pailit diucapkan.

4. Segala perikatan debitor yang timbul sesudah putusan pailit diucapkan tidak dapat dibayar dari harta pailit kecuali jika menguntungkan harta pailit.

5. Harta pailit diurus dan dikuasai kurator untuk keuntungan para kreditor dan debitor. ${ }^{15}$

6. Tuntutan dan gugatan mengenai hak dan kewajiban harta pailit harus diajukan oleh atau terhadap kurator.

7. Semua tuntutan atau yang bertujuan mendapatkan pelunasan suatu perikatan dari harta pailit, dan dari harta debitor sendiri selama kepailitan harus diajukan dengan cara melaporkannya untuk dicocokkan.

8. Dengan memperhatikan ketentuan pasal 56, pasal 57, dan pasal 58 UU No. 37 Tahun 2004 tentang kepailitan dan PKBU, kreditor pemegang hak gadai, jaminan viducia, hak tanggungan, hipotik, atau hak agunan atas kebendaan lainnya, dapat dieksekusi haknya seolah -olah tidak ada kepailitan (pasal 55 ayat 1). UU No 37 Tahun 2004 tentang Kepailitan dan PKPU).

9. Hak eksekusi terhadap debitur yang dijanali sebagai disebut dalam Pasal 55 ayat 1 UU No. 37 Tahun 2004 tentang Kepailitan dan PKPU, dan pihak ketiga

\footnotetext{
${ }^{14}$ Ahmad Rofiq, Hukum Islam Di Indonesia (RajaGrafindo Persada, 1995).

${ }^{15}$ Fathudin Fathudin, Adi Wibowo, and Salsabella Rahma Dewi, "Praktik Muḍārabah Di Bank Muamalat KCP Wonosobo Perspektif Hukum Ekonomi Syariah," HAKAM: Jurnal Kajian Hukum Islam Dan Hukum Ekonomi Islam 4, no. 1 (2020).
} 
untuk menuntut hartanya yang berada dalam penguasaan debitur pailit atau kurator, ditangguhkan maksimum 90 hari setelah keputusan Pailit diucapkan ( Pasal 56 ayat 1 UU No. 37 Tahun 2004 tentang kepailitan dan PKPU)

\section{Pihak-Pihak Yang Terkait Dalam Pengurusan Harta dan Kepailitan}

\section{Hakim pengawas}

Tugas hakim pengawas adalah mengawasi pengurusan dan pemberesan harta pailit yang dilakukan oleh curator, dan sebelum memustuskan sesuatu yang ada sangkut pautnya dengan pengurusan dan pemberesan harta pailit. Pengadilan niaga wajib mendengar nasihat terlebih dahulu dari hakim pengawas. Tugas-tugas dan kewenangan hakim pengawas adalah sebagai berikut ${ }^{16}$ :

a. Memimpin rapi verifikasi

b. Mengawasi tindakan dari curator dalam melaksanakan tugasnya, memberikan nasihat dan peringatan kepada curator atas pelaksanaan tugas tersebut.

c. Menyetujui atau menolak daftar-daftar tagihan yang diajukan oleh para kreditur.

d. Meneruskan tagihan-tagihan yang tidak dapat diselesaikannya dalam rapat verifikasi kepada hakim pengadilan niaga yang memutus perkara itu.

e. Mendengar saksi-saksi dan para ahli atas segala hal yang berkaitan dengan kepailitan (misalnya: tentang keadaan budel, perilaku pailit dan sebagainya).

f. Memberikan izin atau menolak permohonan si pailit untuk bepergian (meninggalkan tempat) kediamannya.

\section{Kurator}

Curator merupakan salah satu pihak yang cukup memegang peranan dalam suatu proses perkara pailit. Dan karena perannya yang besar dan tugasnya yang berat, maka tidak sembarangan orang dapat menjadi pihak curator. Dalam pasal 69 UUK dan PKPU disebutkan, tugas curator adalah melakukan pengurusan dan atau pemberesan harta pailit ${ }^{17}$.

Karena itu pula maka persyaratan dan prosedur untuk dapat menjadi curator ini oleh UUK dan PKPU diatur secara relative ketat. Sewaktu masih berlakunya peraturan kepailitan zaman belanda, hanya balai harta peninggalan (BHP) saja yang dapat menjadi curator tersebut. Dalam pasal 70 ayat (1) UUK dan PKPU disebutkan, yang dapat bertindak menjadi curator sekarang adalah sebagai berikut:

a. Balai harta peninggalan (BHP)

b. Curator lainnya.

\footnotetext{
${ }^{16}$ Ali Miftakhu Rosyad, "THE ACTUALIZATION OF MULTICULTULARISM VALUES THROUGH SOCIAL STUDIES LEARNING AT STATE JUNIOR HIGH SCHOOL 2 JUNTINYUAT IN REGENCY INDRAMAYU BACKGROUND OF THE PROBLEM," n.d.

${ }^{17}$ Ahmad Syathori, "KONSEP WELFARE-ECONOMIC: ANTARA ETIKA BISNIS ISLAM DAN PROTESTAN," Risâlah, Jurnal Pendidikan Dan Studi Islam 3, no. 1 (2016): 78-93.
} 


\section{Panitia kreditur}

Pada prinsipnya, suatu panitia kreditur adalah pihak yang mewakili pihak kreditur, sehingga panitia kreditur tentu akan memperjuangkan segala kepentingan hukum dari pihak kreditur. Ada dua macam panitia kreditur yang diperkenalkan oleh UUK dan PKPU, yaitu:

a. Panitia kreditur sementara

Dalam pasal 79 UUK dan PKPU disebutkan, dalam putusan pailit atau dengan penetapan kemudian, pengadilan dapat membentuk panitia kreditur (sementara) yang terdiri dari satu sampai tiga orang yang dipilih dari kreditur yang dikenal dengan maksud memberikan nasihat kepada curator. Yang dimaksud dengan kreditur yang sudah dikenal adalah kreditur yang sudah mendaftarkan diri untuk diverifikasi.

b. Panitia kreditur tetap

Pasal 72 UUK dan PKPU menyatakan bahwa setelah pencocokan utang selesai dilakukan, hakim pengawas wajib menawarkan pada para kreditur untuk membentuk panitia kreditur tetap ${ }^{18}$.

\section{Penundaan Kewajiban Pembayaran Utang}

Penundaan Kewajiban Pembayaran Utang merupakan alternatif penyelesaian utang untuk menghindari kepailitan. Menurut Undang-Undang Nomor 37 Tahun 2004 tentang Kepailitan dan PKPU Pasal 222 ayat (2) dikatakan : "Debitor yang tidak dapat atau memperkirakan dapat melanjutkan membayar utang-utangnya yang sudah jatuh waktu dan dapat ditagih, dapat memohon penundaan kewajiban pembayaran utang dengan maksud untuk mengajukan rencana perdamaian yang meliputi tawaran pembayaran sebagian atau seluruh utang kepada kreditor".

PKPU pada dasarnya, hanya berlaku/ditujukan pada para kreditor konkuren saja. Walaupun pada Undang-undang No.37 Tahun 2004 pada Pasal 222 ayat (2) tidak disebut lagi perihal kreditor konkuren sebagaimana halnya Undangundang No. 4 Tahun $1998^{19}$.

\section{Pencocokan Piutang}

Pencocokan piutang merupakan salah satu kegiatan yang penting dalam proses kepailitan, karena dengan pencocokan piutang inilah nantinya ditentukan perimbangan dan urutan hak dari masing - masing kreditor, yang dilakukan paling lambat 14 hari sejak putusan pernyataan pailit mempunyai kekuatan hukum tetap. Dalam hal ini hakim pengawas dapat menetapkan :

1. batas akhir pengajuan tagihan

2. batas akhir verifikasi pajak untuk menentukan besarnya kewajiban pajak sesuai denganPeraturan perundang - undangan di bidang perpajakan

3. hari, tanggal, waktu dan tempat rapat kreditor untuk mengadakan pencocokan utang.

\footnotetext{
${ }^{18}$ Republik Indonesia, “Undang-Undang No. 21 Tahun 2008," Tentang Perbankan Syariah. Jakarta, 2008.

19 Bank Indonesia, “Undang-Undang Republik Indonesia No. 10 Tahun 1998 Tentang Perbankan," UndangUndang Republik, 1998.
} 
Kurator berkewajiban untuk melakukan pencocokan antara perhitunganperhitungan yang dimasukkan dengan catatan-catatan dan keterangan- keterangan bahwa debitor telah pailit. Dalam rapat pencocokan piutang, hakim pengawas berkewajiban membacakan daftar piutang yang sementara telah diakui dan oleh curator telah dibantah untuk dibicarakan dalam rapat. Debitor wajib hadir sendiri dalam rapat pencocokan piutang agar dapat memberikan keterangan yang diminta oleh hakim pengawas mengenai sebab musabab kepailitan dan keadaan harta pailit.Dalam Undang-Undang juga terdapat Bab I Pencocokan Utang Piutang Yaitu :Pasal 104-Pasal 133

\section{Perdamaian}

Dalam penyelesaian perkara tentu diusahakan perdamaian sebagaimana dalam Hukum Acara Perdata yang bersumber dari HIR menyatakan bahwa dalam menyelesaikan perkara hakim wajib mengusahakan perdamaian terlebih dahulu. Dalam perkara kepailitan perdamaian tidak diusahakan di awal, karena hakim hanya diberi waktu 60 hari untuk mengeluarkan putusan ${ }^{20}$.

Perdamaian dalam kepailitan justru diusahakan setelah putusan yang menyatakan bahwa debitor dalam keadaan pailit. Berdasarkan Pasal 144 UUK debitor pailit berhak untuk menawarkan suatu perdamaian kepada semua kreditor. Perdamaian merupakan perjanjian antara debitor dengan para kreditor dimana debitor menawarkan pembayaran sebagian dari utangnya dengan syarat bahwa ia setelah melakukan pembayaran tersebut dibebaskan dari sisa utangnya, sehingga ia tidak mempunyai utang lagi ${ }^{21}$.

\section{Permohonan Peninjauan Kembali}

Terhadap putusan kepailitan yang telah mempunyai kekuatan hukum tetap, dapat diadakan peninjauan kembali. Imran Naning menyebutkan bahwa upaya hukum peninjauan kembali dapat dilakukan apabila:

1. terdapat bukti baru yang penting, yang apabila diketahui pada tahappersidangan sebelumnya, akan menghasilkan putusan yang berbeda atau

2. Pengadilan Niaga/putusan hakim yang bersangkutan terdapat kekeliruan yang nyata.

Sutan Remy Sjahdeini menyebutkan bahwa upaya hukum peninjauan kembali diajukan paling lambat 180 hari setelah tanggal putusan yang dimohonkan peninjauan kembali memperoleh kekuatan hukum tetap, namun dengan alasan sebagaimana yang dimaksud dalam Pasal 295 Ayat (2) huruf a UUK-PKPU. Apabila upaya hukum peninjauan kembali dilakukan dengan alasan sebagaimana yang dimaksud dalam Pasal 295 Ayat (2) huruf b UUK-PKPU, maka peninjauan kembali dilakukan paling lambat 30 hari setelah tanggal putusan yang dimohonkan peninjauan kembali memperoleh kekuatan hukum tetap.

\footnotetext{
${ }^{20}$ Fawaid, Zamroni, and Baharun, "Contesting Sacred Architecture: Politics of 'Nation-State'in the Battles of Mosques in Java."

${ }^{21}$ Ugin Lugina, "Pengembangan Ekonomi Pondok Pesantren Di Jawa Barat," Risâlah, Jurnal Pendidikan Dan Studi Islam 4, no. 1 (2017): 53-64.
} 


\section{Karakteristik Hukum Perburuhan Indonesia}

Hukum perburuhan (arbeidsrecht/labour law) merupakan hukum yang mengatur mengenai hal ihwal hubungan kerja yang terjadi antara pengusaha sebagai pengendali perusahaan yang merupakan pemberi perintah (kerja) dengan pekerja/buruh sebagai penerima perintah (untuk bekerja) serta pemerintah yang berfungsi sebagai regulator, supervisor, dan pelayanan didalamnya. Dari batasan mengenai hukum perburuhan tersebut, maka terdapat beberapa unsur yang menjadi bagian dari hukum perburuhan yang penting yaitu:

a. Adanya hubungan kerja;

b. Adanya pihak pengusaha dan buruh/pekerja;

c. Terdapatnya peran pemerintah.

Hubungan kerja dalam hubungan industrial memiliki tiga unsur utama, yaitu, adanya pekerjaan, adanya perintah, dan adanya upah. Unsur perintah ini berarti bahwa hubungan industrial bersifat sub-ordinasi, dimana pengusaha mememiliki kedudukan diatas yang berfungsi memberikan perintah, sedangkan pekerja memiliki posisi dibawah pengusaha yang berfungsi menjalankan perintah dari pengusaha.

Pihak perusahaan/pengusaha merupakan pihak yang menginisiasi terjadinya hubungan kerja. Sebagai pihak yang menginisiasi hubungan kerja, pengusaha akan melakukan rekruitmen terhadap pekerja/buruh, dan setelah masuk menjadi pekerja/buruh, maka pengusaha yang mempekerjakan pekerja/buruh dibawah perintahnya. Perintah tersebut baik dalam bentuk lisan maupun tertulis, baik dalam bentuk formal seperti dimuat dalam perjanjian kerja, peraturan perusahaan, perjanjian kerja bersama, maupun aturan perusahaan lainnya maupun dalam bentuk informal, seperti pengumuman, instruksi kerja, dan surat edaran ${ }^{22}$.

Pihak pekerja/buruh bekerja di perusahaan milik pengusaha dan pekerja tersebut memiliki kedudukan subordinasi dari pengusaha/perusahaan. Pekerjaan yang dilakukan pekerja/buruh merupakan pelaksanaan dari apa yang diperintah atau yang diinginkan oleh pengusaha, sehingga tentu sesuatu yang dikerjakan pekerja/buruh akan memberikan manfaat bagi pengusaha/perusahaan. Pekerja/ buruh menjadi pekerja/buruh dari perusahaan tentu atas seleksi dari perusahaan.

Sistem hukum perburuhan, khususnya di Indonesia, maka norma yang berlaku adalah terdiri atas norma heteronom dan norma otonom. Norma heteronom adalah ketentuan-ketentuan hukum di bidang perburuhan yang dibuat oleh pihak ketiga yang posisinya di luar pihak-pihak yang terikat oleh suatu hubungan kerja antara pihak pengusaha dengan pihak pekerja. Pihak ketiga yang paling dominan yang sangat strategis disini adalah pemerintah/negara. Oleh karena itu, bentuk norma heteronom adalah semua peraturan perundang-undangan dan peraturan kebijakan di bidang perburuhan yang ditetapkan oleh pemerintah/negara yang $\operatorname{sah}^{23}$.

Prinsip dalam hukum perburuhan yang menentukan bahwa kesepakatan antara pengusaha dengan pekerja demi hukum tidak berlaku apabila bertentangan

\footnotetext{
${ }^{22}$ Hasanah, “Faktor-Faktor Yang Mempengaruhi Kepuasan Kerja Guru," Manajer Pendidikan 9, no. 1 (2015): 93.

${ }^{23}$ Suhrawardi K. Lubis, Hukum Ekonomi Islam, 3rd ed. (Jakarta: Sinar Grafika, 2004).
} 
dengan ketentuan peraturan perundang-undangan karena kesepakatan yang diberikan oleh pekerja dianggap dalam kondisi keterpaksaan. Kondisi keterpaksaan dari pekerja karena kebutuhan pekerja untuk tetap bekerja di perusahaan, dan jika pekerja tidak menyepakati ketentuan perusahaan maka akan diputus hubungankerjanya oleh perusahaan. Pekerja sangat takut apabila di PHK oleh perusahaan, karena apabila di PHK maka pekerja akan kesulitan untuk bisa bekerja di perusahaan lain karena jumlah lowongan kerja jauh lebih sedikit daripada tenaga kerja yang membutuhkan kerja. Badan Pusat Statistik (BPS) mencatat bahwa angka pengangguran yang tercatat saja sudah mencapai angka kurang lebih 6,8 juta orang atau sekitar $5 \%$ dari jumlah angkatan kerja di Indonesia.

\section{Karakteristik hukum kepailitan Indonesia}

Di Indonesia, kepailitan digunakan sebagai instrumen hukum bagi orang atau perusahaan yang gagal membayar kewajiban utangnya pada pihak lain. Kegagalan membayar tersebut bisa ada keterkaitannya dengan kebangkrutan dan kesulitan keuangan dari debitor, bisa pula kepailitan tersebut sama sekali tidak terkait dengan kebangkrutan dan kesulitan keuangan dari debitor. Kepailitan di Indonesia hanya ditujukan kepada debitor karena keengganan dari debitor untuk memenuhi kewajiban membayar utang tersebut dan tidak dikaitkan dengan kebangkrutan, kesulitan keuangan, atau solvabilitas asset dan keuangan. Tindakan tidak membayarnya debitor tersebut dilatarbelakangi oleh banyak hal.

Politik hukum kepailitan dalam sistem hukum di Indonesia lebih difungsikan sebagai mekanisme penagihan utang, dan bukan mekanisme jalan keluar terhadap debitor yang mengalami kesulitan keuangan, debitor yang mengalami kebangkrutan, maupun debitor yang sedang insolven (yakni memiliki utang yang lebih besar dari asetnya) ${ }^{24}$.

Politik hukum kepailitan di Indonesia yang tidak melihat apakah perbuatan debitor yang tidak melakukan pembayaran itu karena ketidakmampuan ataukah karena ketidakmauan, itu hampir sama kepailitan yang berlaku di Belanda saat ini. Hal ini dapat dipahami, oleh karena sistem hukum kepailitan di Indonesia dibangun pertama kali dengan memberlakukan Peraturan Kepailitan (Faillissement Verordening) yang merupakan warisan kolonial Belanda. Demikian pun sistem hukum kepailitan di Belanda banyak

kemiripannya dengan sistem hukum kepailitan di Perancis dan sistem hukum kepailitan di Jerman, karena tidak bisa dilepaskan dengan sejarah hukumBelanda dengan sejarah hukum Perancis dan Jerman. Tiadanya syarat kepailitan mengenai adanya keadaan insolvensi, dapat terlihat dari ketentuan syarat permohonan pailit yang diatur dalam Pasal 2 ayat (1) junto Pasal 8 ayat (4) UU Kepailitan dan PKPU. Ketentuan tersebut hanya mensyaratkan dua hal ditambah satu hal. Dua hal tersebut adalah adanya utang yang tidak dibayar lunas dan dapat ditagih serta adanya minimal dua kreditor. Sedangkan satu hal lagi adalah sistem pembuktian dalam kepailitan yang menggunakan sistem pembuktian sederhana.

\footnotetext{
${ }^{24}$ Sulaiman Rasjid, “Fiqh Islam (Hukum Fiqh Lengkap), Cet,” XXXIV, Bandung: Sinar Baru Algensindo, 2001.
} 
Dalam Pasal 2 ayat (1) junto Pasal 8 ayat (4) UU Kepailitan dan PKPU tersebut sama sekali tidak mensyaratkan adanya ketidaksolvenan (insolven) debitor.

Hukum kepailitan Indonesia telah mengalami reformasi yang sangat progresif pada tahun 1998 dan 2004, yakni dengan lahirnya UU No. 4 Tahun 1998, yang kemudian digantikan dengan UU No. 37 Tahun 2004. UU Kepailitan 1998 mengubah persyaratan materiil untuk mengajukan permohonan pailit. UU Kepailitan ini memudahkan syarat permohonan pailit dibandingkan dengan peraturan kepailitan sebelumnya ${ }^{25}$.

Dalam UU Kepailitan 2004 mensyaratkan utang yang dijadikan dasar pailit adalah utang yang tidak dibayar lunas. Ketentuan "tidak membayar lunas" memiliki arti bahwa utang/angsuran utang tidak dibayar lunas dan tuntas dari kewajiban yang seharusnya. Jika debitor hanya membayar sebagian dari kewajiban seharusnya maka ia masuk kategori "tidak membayar lunas" karenanya memenuhi salah satu syarat untuk dimohonkan pailit. Ketentuan ini lahir karena berdasarkan penelitian banyak debitor yang beritikad buruk yang untuk menghindari dipailitkan maka dengan cara membayarhanya sebagian kecil saja. UU Kepailitan tidak memberikan ruang gerak sedikitpun terhadap debitor yang mempunyai persoalan dengan pembayaran utangnya untuk melakukan restrukturisasi terhadap skema pembayaran utang.

\section{Pengajuan Kepailitan oleh Buruh terhadap Perusahaan yang tidak memenuhi hak normatif buruh}

Dalam hubungan kerja antara pengusaha dengan pekerja, tidak jarang terjadi perselisihan diantara keduanya ${ }^{26}$. Perselisihan antara pengusaha dengan pekerja disebabkan berbagai sebab, bisa terjadi karena perbuatan atau kepentingan pengusaha, bisa terjadi karena perbuatan atau kepentingan pekerja, bisa pula terjadi bukan karena kehendak pengusaha mamupun kehendak pekerja. Sering terjadinya perselisihan tersebut, maka hukum memiliki peranan yang strategis untuk menyelesaikanperselisihan tersebut.

Dalam sistem penyelesaian perselisihan hubungan industrial di Indonesia, perselisihan hubungan industrial dibagi menjadi empat jenis, yaitu: perselisihan hak, perselisihan kepentingan, perselisihan pemutusan hubungan kerja, dan perselisihan antar serikat pekerja dalam satu perusahaan. Keempat jenis perselisihan tersebut akan menentukan prosedur penyelesaian perselisihannya

Perselisihan PHK merupakan pertentangan pendapat yang terjadi antara pengusaha dengan pekerja yang terjadi karena tidak adanya kesesuaian pendapat mengenai hal ihwal pengakhiran hubungan kerja yang dilakukan oleh salah satu pihak. Perselisihan Pemutusan hubungan kerja ini paling banyak terjadi didalam perselisihan hubungan industrial ${ }^{27}$.

Penyelesaian perselisihan hubungan industrial melalui sistem pengadilan

\footnotetext{
${ }^{25}$ Ali, Sistem Ekonomi Islam: Zakat Dan Wakaf.

${ }^{26}$ Ekonomi Islam Rozalinda, "Teori Dan Aplikasinya Pada Aktivitas Ekonomi Jakarta" (Rajawali Press, 2016).

${ }^{27}$ Ali Miftakhu Rosyad, "The IMPLEMENTASI NILAI-NILAI MULTIKULTURALISME MELALUI PEMBELAJARAN PENDIDIKAN AGAMA ISLAM (THE IMPLEMENTATION OF MULTICULTURALISM VALUES THROUGH LEARNING OF ISLAMIC RELIGION EDUCATION)," Risâlah, Jurnal Pendidikan Dan Studi Islam 5, no. 1 (2019): 1-18.
} 
hubungan industrial tersebut sering menemukan banyak kendala didalam proses maupun hasilnya. Kendala tersebut adalah antara lain jangka waktu proses penyelesaian yang lama. Penelitian yang dilakukan oleh Lembaga bantuan Hukum (LBH) Jakarta yang meneliti sejumlah 2.993 putusan dari tahun 2006 - 2013, menemukan terdapat salah satu putusan perselisihan hubungan industrial yang sampai memakan waktu 2.611 hari (7 tahun). Lamanya proses penyelesaian perselisihan ini tentu akan sangat merugikan pihak pekerja, karena kepastian hukum yang lama akan menggantung kejelasan status maupun hak dari pekerja, sementara ketahanan pekerja untuk bertahan dalam status yang tidak pasti tersebut sangat rentan.

Kendala yang lain yang dihadapi pekerja dalam penyelesaian perselisihan hubungan industrial di pengadilan hubungan industrial adalah sulitnya mengeksekusi putusan akhir dari pengadilan. Meskipun pekerja telah memenangi perkara yang diajukan ke pengadilan, dalam hal ini Pengadilan Hubungan Industrial, namun demikian kemenangan tersebut seringkali hanyalah kemenangan diatas kertas. Putusan pengadilan seringkali tidak bisa dieksekusi, terutama putusan yang amarnya memerintahkan kepada pengusaha untuk mempekerjakan kembali pekerja.

Kendala yang dihadapi pekerja dalam menyelesaikan perselisihan dengan pengusaha melalui mekanisme penyelesaian perselisihan hubungan industrial tersebut, menyebabkan pekerja mencari alternatif upaya hukum lain. Salah satu upaya hukum lain yang cenderung digunakan oleh pekerja adalah mengajukan permohonan pailit terhadap perusahaan dengan dasar tidak dibayarnya hak-hak normatif pekerja yang seharusnya dibayar oleh perusahaan akan tetapi oleh perusahaan tidak dibayar ${ }^{28}$.

oleh pekerja karena tidak dibayarnya hak pekerja merupakan fenomena yang unik sekaligus menarik untuk dikaji lebih dalam. Hal ini karena terkait dengan tujuan penggunaan instrumen hukum kepailitan dan pemenuhan syarat permohonan kepailitan serta efektifitas penggunaan instrumen kepailitan oleh pekerja tersebut. Disamping itu pula penggunaan instrumen hukum kepailitan ini bisa menjadi boomerang bagi semua pekerja itu sendiri, oleh karena apabila perusahaan dinyatakan pailit maka kegiatan perusahaan akan berhenti dan tentu semua pekerja di perusahaan pailit tersebut akan terkena PHK.

Dalam konteks tema riset ini, maka kewajiban perusahaan untuk memenuhi hak-hak pekerja yang kemudian perusahaan tidak melakukan kewajiban tersebut maka kewajiban yang tidak dilaksanakan ini dapat dikualifikasi sebagai utang. Utang yang tidak dibayar oleh perusahaan ini dapat dijadikan sebagai dasar untuk mengajukan permohonan pailit oleh pekerja terhadap perusahaan tersebut.

Syarat materiil pertama yang harus dibuktikan dalam permohonan pailit adalah adanya utang debitor yang tidak dibayar lunas yang telah jatuh waktu dan dapat ditagih. Utang dalam hukum kepailitan mencakup semua kewajiban yang

\footnotetext{
${ }^{28}$ Lufaefi Lufaefi, “HARMONISM THE JURISPRUDENCE OF JA'FARI AND HANAFI: HISTORICAL STUDY AND BOTH LEGAL SOURCES (HARMONISME FIKIH JA'FARI DAN HANAFI: KAJIAN HISTORIS DAN SUMBER-SUMBER HUKUM KEDUANYA)," Al-Afkar, Journal For Islamic Studies 3, no. 1 (2019): 235-46.
} 
timbul dari perikatan yang harus ditunaikan oleh debitor baik kewajiban itu timbul karena perjanjian maupun kewajiban tersebut timbul karena ada peraturan perundang- undangan yang mengharuskan adanya kewajiban tersebut ${ }^{29}$.

Adapun unsur utang yang harus didalilkan sebagai syarat pengajuan permohonan pailit terhadap debitor adalah bahwa utang tersebut harus tidak dibayar lunas. Ketentuan ini untuk menegaskan bahwa apabila debitor sudah membayar akan tetapi jumlah pembayarannya baru sebagian dari jumlah yang seharusnya dibayar, maka tetap saja debitor itu dapat dikualifikasi bahwa utangnya tidak dibayar lunas. Ketentuan ini untuk menegaskan bahwa kewajiban debitor untuk membayar utang adalah secara lunas sesuai dengan perikatan yang dibuatnya. Utang tersebut juga harus sudah jatuh waktu. Jatuh tempo suatu utang dapat saja karena memang suatu waktu tertentu yang sudah ditentukan dalam perjanjiannya, namun dapat pula karena sebab lain yang didasarkan pada suatu sebab atau kejadian tertentu. Utang tersebut juga harus merupakan utang yang dapat ditagih, yakni utang tersebut memang menurut hukum dibenarkan untuk ditagih. Hal ini karena ada utang yang menurut hukum tidak dibenarkan untuk ditagih, yakni utang yang timbul dari suatu perikatan alami (natuurlijke verbintenis), seperti utang yang timbul karena daluarsa dan utang yang timbul karena perjudian yang dilarang oleh hukum ${ }^{30}$.

Terkait dengan hak-hak pekerja yang tidak dibayar oleh pengusaha, maka hal tersebut dapat dikualifikasi sebagai utang pengusaha kepada pekerja, sehingga pengusaha memiliki kewajiban untuk membayarnya kepada pekerja yang berhak. Adapun syarat yang kedua dalam permohonan pailit adalah debitor memiliki paling sedikit dua kreditor. Kreditor merupakan pihak yang memiliki suatu piutang baik yang lahir karena suatu perjanjian atau pun yang lahir karena suatu ketentuan peraturan perundang-undangan yang dapat ditagih di muka pengadilan.

Pekerja yang tidak dibayar haknya oleh perusahaan merupakan kreditor preferen. Digolongkannya pekerja sebagai kreditor preferen, oleh karena terdapat ketentuan dalam peraturan perundang-undangan yang menentukan bahwa hak-hak pekerja harus didahulukan pembayarannya. Pasal 95 ayat (4) UU No. 13 Tahun 2003 tentang Ketenagakerjaan menentukan bahwa apabila perusahaan dinyatakan pailit oleh pengadilan berdasarkan peraturan peraturan perundangundangan yang berlaku (dalamhal ini peraturan perundang-undangan di bidang hukum kepailitan, yakni berdsasar UU Kepailitan dan PKPU), maka hak-hak pekerja/buruh baik hak upah maupun hak normatif lainnya didahulukan pembayarannya dibandingkan dengan kreditor lain. Demikian pula dalam Putusan Mahkamah Konstitusi RI Nomor 67/PUU-XI/2013menentukan bahwa upah buruh didahulukan dari semua kreditor dan pesangon didahulukan dari tagihan pajak dan kreditor lainnya.

Dalam praktik di pengadilan, sudah terdapat putusan pengadilan niaga yang memutus pailit atau penundaan kewajiban pembayaran utang (PKPU) yang berujung pailit yang diajukan oleh pekerja terhadap perusahaan karena perusahaan

\footnotetext{
${ }^{29}$ Hasanah, "Faktor-Faktor Yang Mempengaruhi Kepuasan Kerja Guru."

${ }^{30}$ Mansur, Seluk Beluk Ekonomi Isla (Salatiga: STAIN Salatiga Press, 2009).
} 
tidak membayar hak- hak normatif yang menjadi hak pekerja. Hak normatif pekerja yang tidak dibayar tersebut dikualifikasi sebagai utang yang merupakan salah satu syarat permohonan pailit. Putusan pengadilan tersebut adalah dalam perkara permohonan PKPU oleh sejumlah pekerja terhadap Perusahaan PT. Gema Ista Raya, Pasuruan, Indonesia. Sejumlah pekerja mengajukan permohonan PKPU terhadap perusahaan karena tidak membayar hak-hak pekerja, yaitu upah yang tertunggak, tunjangan hari raya, dan pesangon PHK. Kewajiban perusahaan untuk membayar hak-hak pekerja tersebut bahkan telah ada putusan pengadilan hubungan industrial yang telah memiliki kekuatan hukum yang tetap (inkracht van gewijsde), namun perusahaan tetap tidak memenuhi pembayaran hak-hak para pekerja tersebut ${ }^{31}$.

Dalam kasus PKPU PT. Gema Ista Raya tersebut oleh majelis hakim Pengadilan Niaga pada pengadilan Negeri Surabaya dipandang telah memenuhi persyaratan permohonan pailit, yaitu perusahaan tidak membayar utang yang berupa hak-hak pekerja, serta memiliki minimal dua kreditor karena yang mengajukan permohonan PKPU lebih dari dua pekerja disamping juga memiliki kreditor perbankan. Demikian pula majelis hakim berpendapat bahwa permohonan PKPU tersebut telah memenuhi persyaratan pembuktian sederhana, oleh karena disamping telah ada nota dari pegawai pengawas ketenagakerjaan juga telah ada putusan dari Pengadilan Hubungan Industrial yang telah memiliki kekuatan hukum yang tetap (inkracht van gewijsde). Setelah dinyatakan PKPU oleh pengadilan, ternyata dalam proses PKPU tersebut tidak tercapai perdamaian antara perusahaan dengan para kreditornya, sehingga PT. Gema Ista Raya dinyatakan pailit oleh pengadilan.

Adapun syarat tambahan yang merupakan syarat formal dalam permohonan kepailitan adalah syarat pembuktian yang sederhana. Persyaratan pembuktian sederhana ditentukan dalam Pasal 8 ayat (4) UU Kepailitan dan PKPU. Pasal 8 ayat (4) UU Kepailitan dan PKPU menentukan bahwa permohonan pailit harus dibuktikan dalam persidangan dengan pembuktian yang sederhana terhadap syarat kepailitan, yakni, syarat adanya minimal satu utang yang tidak dibayar lunas yang telah jatuh waktu dan dapat ditagih serta syarat adanya minimal dua kreditor yang dimiliki oleh debitor. UU Kepailitan dan PKPU tidak menentukan batasan dari pembuktian sederhana, hanya dalam Penjelasan Pasal 8 ayat (4) UU Kepailitan dan PKPU menjelaskan bahwa pembuktian secara sederhana tersebut merupakan pembuktianadnya fakta dua atau lebih kreditor yang dimiliki oleh debitor serta fakta adanya utang yang tidak dibayar yang telah jatuh tempo, sedangkan perbedaan besar kecilnya jumlah utang yang didalilkan dalam permohonan tidak menjadi halangan untu ditetapkanya putusan pernyataan pailit oleh hakim pengadilan niaga.

Norma Pasal 8 ayat (4) UU Kepailitan berikut penjelasan Pasal 8 ayat (4) sangat kabur (vague norm) karena tidak secara pasti memberikan batasan mengenai yang dimaksud dengan pembuktian sederhana. Demikian juga di dalam hukum acara perdata umum, tidak dikenal konsep pembuktian sederhana. Sehingga penerapan pembuktian sederhana menimbulkan beberapa permasalahan di pengadilan.

\footnotetext{
${ }^{31}$ Fathudin, Wibowo, and Dewi, "Praktik Muḍārabah Di Bank Muamalat KCP Wonosobo Perspektif Hukum Ekonomi Syariah."
} 
Menurut Kartini Mulyadi, menyatakan bahwa yang dimaksud dengan pembuktian yang sederhana dalam permohonan pailit adalah pembuktian sederhana terhadap keberadaandari suatu utang yang dimiliki oleh debitor termohon pailit yang telah jatuh tempo dan dapat ditagih, serta keberadaan adanya minimal dua kreditor dari debitor termohon pailit.

Pengajuan permohonan pailit oleh pekerja tersebut, tidak diharuskan adanya putusan dari Pengadilan Hubungan Industrial (PHI) terlebih dahulu. Hal ini karena jika sudah ada penetapan dari pegawai pengawas ketenagakerjaan, dan penetapan tersebut tidak dibantah oleh pengusaha, maka hal tersebut cukup untuk memenuhi persyaratan pembuktian sederhana, tanpa harus ada putusan dari pengadilan hubungan industrial terlebih dahulu. Namun demikian apabila ada putusan dari pengadilan juga hal tersebut lebih baik. Hal ini karena jika diharuskan dengan melampirkan putusan PHI, maka apabila tidak ada gugat menggugat di PHI, hal tersebut berarti menghalangi pekerja untuk melakukan upaha hukum jalur kepailitan ini, dan ini berarti menegasikan pemenuhan keadilan bagi pekerja tersebut $^{32}$.

Kasus permohonan PKPU yang berujung kepailitan oleh pekerja terhadap perusahaan PT. Sasana Taruna Aneka Ria, menunjukkan bahwa pekerja dapat melakukan upaya hukum atas hak-haknya yang tidak dibayar oleh perusahaan, yaitu hak yang berupa upah yang belum dibayar, uang pesangon, serta hak lainnya (hak cuti). Hak-hak yang belum dibayar tersebut telah diakui oleh perusahaan yang dituangkan dalam dokumen perjanjian bersama antara perusahaan dengan pekerja. Atas belum terbayarnya hak-hak pekerja tersebut, pekerja tidak menempuh upaya hukum ke pengadilan hubungan industrial, melainkan mengajukan permohonan PKPU ke pengadilan niaga. Atas permohonan PKPU tersebut, Pengadilan Niaga pada Pengadilan Negeri Surabaya mengabulkan permohonan pekerja tersebut dan menyatakan perusahaan berstatus PKPU. Setelah dilakukan proses perdamaian dalam PKPU, ternyata tidak disetujui oleh para kreditornya sehingga perusahaan dinyatakan pailit.

Dalam kasus PKPU yang berakhir dengan kepailitan PT. Sasana Taruna Aneka Ria, pengadilan berpendapat bahwa telah memenuhi persyaratan untuk PKPU/kepailitan, yaitu adanya utang yang tidak dibayar yang berupa hak upah dan hak pesangon, serta memiliki lebih dari dua kreditor. Disamping itu juga pengadilan berpendapat bahwa kasus a quo memenuhi pembuktian sederhana karena telah ada kesepakatan bersama antara perusahaan dengan pekerja mengenai hak-hak pekerja yang belum dipenuhi. Kasus PT. Sasana Taruna Aneka Ria ini menunjukkan bahwa perselisihan antara pengusaha dengan pekerja tersebut, tidak harus diselesaikan terlebih dahulu di pengadilan hubungan industrial baru dibawa ke pengadilan niaga untuk dipailitkan ${ }^{33}$.

\footnotetext{
${ }^{32}$ Rudy Hariyanto, “Menumbuhkan Semangat Wirausaha Menuju Kemandirian Ekonomi Umat Berbasis Pesantren (Studi Kasus Di PP Darul Ulum Banyuanyar Pamekasan)," NUANSA: Jurnal Penelitian Ilmu Sosial Dan Keagamaan Islam 14, no. 1 (2017): 185-212.

${ }^{33}$ Oktaf B Kharisma et al., "Development of Location Tracking System via Short Message Service (SMS) Based on GPS Unblox Neo-6m and Sim 800I Module," Journal of Physics: Conference Series 1363 (2019): 12002, https://doi.org/10.1088/1742-6596/1363/1/012002.
} 
Pengajuan kepailitan atau PKPU yang diajukan oleh pekerja terhadap perusahaan yang karena perusahaan tidak membayar hak-hak pekerja ini memiliki beberapa keunggulan dibandingkan dengan upaya hukum lain, meskipun juga memiliki kelemahan pada aspek lain. Keunggulan penggunaan upaya hukum tersebut adalah penyelesaian kepailitan yang memakan waktu relatif singkat dalam persidangan kepailitan. Persidangan permohonan kepailitan harus sudah diputus oleh hakim dalam waktu paling lambat 6o hari sejak permohonan didaftarkan ke pengadilan.

Namun demikian, meskipun penggunaan instrumen kepailitan oleh pekerja terhadap pengusaha yang tidak memenuhi hak pekerja memiliki kelebihan tersebut, akan tetapi memiliki kelemahan yang cukup mendasar yaitu tutupnya dan bahkan bubarnya perusahaan karena kepailitan tersebut. Apabila perusahaan tersebut tutup dan bubar, tentu akan menyebabkan PHK terhadap semua pekerja dari perusahaan dan bahkan hak-hak pekerja secara keseluruhan bisa tidak tercukupi untuk dibayar dari hasil pemberesan harta pailit. Memang terhadap perusahaan debitor pailit, dapat dilanjutnya usahanya (on going concern) meski badan hukumnya berstatus pailit, akan tetapi sangat jarang sekali usaha debitor pailit dapat menyelesaikan seluruh utang- utangnya yang berarti kepailitan debitor akan diakhiri dan dapat dibubarkan.

\section{Simpulan}

Dari pembahasan diatas dapat diambil kesimpulan bahwa Yang dapat dinyatakan mengalami kepailitan adalah debitur yang sudah dinyataka tidak mampu membayar utang- utangnya lagi. Hal ini berdasarkan pasal 1 angka 1 Undang-Undang Nomor 37 Tahun 2004 tentang Kepailitan dan Penundaan Kewajiban Pembayaran Utang (PKPU), Kepailitan adalah sita umum atas semua kekayaan debitor pailit yang pengurusan dan pemberesannya dilakukan oleh kurator di bawah pengawasan hakim pengawas sebagaimana diatur dalam undangundang ini.

Pekerja seringkali mengalami kendala dalam upaya hukum melalui mekanisme penyelesaian perselisihan hubungan industrial (PPHI) terkait dengan hak-hak normatifnya yang tidak dibayar oleh perusahaan, seperti upah, jaminan sosial dan peasngon PHK. Kendala tersebut adalah antara lain adalah karena jangka waktu penyelesaian perselisihan yang lama dan berlarut-larut, serta sulitnya mengeksekusi putusan pengadilan hubungan industrial. Lamanya proses penyelesaian perselisihan hubungan industrial sangat merugikan pekerja karena pekerja akan menanti waktu yang lama untuk mendapatkan kepastian status hak yang dituntut. Sedangkan sulitnya eksekusi putusan pengadilan hubungan industrial karena terkait dengan biaya yang harus dikeluarkan terlebih dahulu serta sulitnya memerintahkan pengusaha untuk mempekerjakan kembali.

Banyaknya kendala dalam penyelesaian melalui pengadilan hubungan industrial tersebut, pekerja memilih alternatif upaya hukum lain, yaitu mengajukan permohonan kepailitan terhadap pengusaha yang didasarkan karena pengusaha tidak menunaikan hak- hak pekerja. Penggunaan upaya hukum kepailitan ini dapat 
dibenarkan dengan harus memenuhi syarat-syarat permohonan pailit yaitu, bukti adanya hak normatif pekerja yang tidak dibayar, bukti adanya perusahaan memiliki minimal dua kreditor, serta proses pembuktian yang sederhana.

Dalam praktik di pengadilan niaga yang memiliki kewenangan mengadili permohonan kepailitan, upaya hukum pengajuan kepailitan oleh pekerja terhadap perusahaan yang tidak membayar hak-hak normatifnya telah ada beberapa kasus yang diputus oleh pengadilan tersebut, seperti dalam kasus di PT. Gema Ista Raya dan di PT. Sasana Taruna Aneka Ria, yang diputus oleh Pengadilan Niaga pada Pengadilan Negeri Surabaya.

\section{DAFTAR USTAKA}

Ali, Mohammad Daud. Sistem Ekonomi Islam: Zakat Dan Wakaf. Penerbit Universitas Indonesia, 1988.

Arifin, Zainul, and Irsan Irsan. "Korupsi Perizinan Dalam Perjalanan Otonomi Daerah Di Indonesia." Lex Librum: Jurnal Ilmu Hukum 5, no. 2 (2019): 887-96.

Baharun, Hasan, Moh Tohet, Juhji Juhji, Siti Maryam Munjiat, Adi Wibowo, and Siti Zainab. "MODERNISASI PENDIDIKAN DI PONDOK PESANTREN: Studi Tentang Pemanfaatan Sistem Aplikasi Pedatren Dalam Meningkatkan Mutu Layanan Pondok Pesantren.” Al-Tarbawi Al-Haditsah: Jurnal Pendidikan Islam 6, no. 1 (2021): 1-22.

Baharun, Hasan, Adi Wibowo, and Siti Nur Hasanah. "Kepemimpinan Perempuan Dalam Menciptakan Sekolah Ramah Anak." Quality 9, no. 1 (2021): 87-102.

Fathudin, Fathudin, Adi Wibowo, and Salsabella Rahma Dewi. "Praktik Muḍārabah

Di Bank Muamalat KCP Wonosobo Perspektif Hukum Ekonomi Syariah." HAKAM: Jurnal Kajian Hukum Islam Dan Hukum Ekonomi Islam 4, no. 1 (2020).

Fawaid, Achmad, Zamroni Zamroni, and Hasan Baharun. "Contesting Sacred Architecture: Politics of 'Nation-State'in the Battles of Mosques in Java." QIJIS (Qudus International Journal of Islamic Studies) 7, no. 1 (2019): 129-72.

Fikri. "Transformation the Value of Al-Islah in the Diversity of Conflict: Epistemology Islamic Law in the Qur'an.” Al-Risalah: Forum Kajian Hukum Dan Sosial Kemasyarakatan 16, no. 2 (2016): 201-16.

Hariyanto, Rudy. "Menumbuhkan Semangat Wirausaha Menuju Kemandirian Ekonomi Umat Berbasis Pesantren (Studi Kasus Di PP Darul Ulum Banyuanyar Pamekasan).” NUANSA: Jurnal Penelitian Ilmu Sosial Dan Keagamaan Islam 14, no. 1 (2017): 185-212.

Hasanah. "Faktor-Faktor Yang Mempengaruhi Kepuasan Kerja Guru." Manajer Pendidikan 9, no. 1 (2015): 93.

Indonesia, Bank. "Undang-Undang Republik Indonesia No. 10 Tahun 1998 Tentang Perbankan.” Undang-Undang Republik, 1998.

Indonesia, Republik. “Undang-Undang No. 21 Tahun 2008." Tentang Perbankan Syariah. Jakarta, 2008. 
Kharisma, Oktaf B, A A Dzikra, Mustakim, Rian Vebrianto, Rice Novita, Hasbullah, Irawati, et al. "Development of Location Tracking System via Short Message Service (SMS) Based on GPS Unblox Neo-6m and Sim 8ool Module." Journal of Physics: Conference Series 1363 (2019): 12002. https://doi.org/10.1088/17426596/1363/1/012002.

Lubis, Suhrawardi K. Hukum Ekonomi Islam. 3rd ed. Jakarta: Sinar Grafika, 2004.

Lufaefi, Lufaefi. "HARMONISM THE JURISPRUDENCE OF JA'FARI AND HANAFI: HISTORICAL STUDY AND BOTH LEGAL SOURCES (HARMONISME FIKIH JA'FARI DAN HANAFI: KAJIAN HISTORIS DAN SUMBER-SUMBER HUKUM KEDUANYA)." Al-Afkar, Journal For Islamic Studies 3, no. 1 (2019): 235-46.

Lugina, Ugin. "Pengembangan Ekonomi Pondok Pesantren Di Jawa Barat." Risâlah, Jurnal Pendidikan Dan Studi Islam 4, no. 1 (2017): 53-64.

Mansur. Seluk Beluk Ekonomi Isla. Salatiga: STAIN Salatiga Press, 2009.

Nopirin, Nopirin. "Pengantar Ilmu Ekonomi Makro Dan Mikro." Yogyakarta: BPFE UGM, 2000.

Rasjid, Sulaiman. "Fiqh Islam (Hukum Fiqh Lengkap), Cet.” XXXIV, Bandung: Sinar Baru Algensindo, 2001.

Rofiq, Ahmad. Hukum Islam Di Indonesia. RajaGrafindo Persada, 1995.

Rosad, Ali Miftakhu. "IMPLEMENTASI PENDIDIKAN KARAKTER MELALUI MANAGEMEN SEKOLAH.” Tarbawi: Jurnal Keilmuan Manajemen Pendidikan 5, no. 02 (2019): 173-90.

Rosyad, Ali Miftakhu. “THE ACTUALIZATION OF MULTICULTULARISM VALUES THROUGH SOCIAL STUDIES LEARNING AT STATE JUNIOR HIGH SCHOOL 2 JUNTINYUAT IN REGENCY INDRAMAYU BACKGROUND OF THE PROBLEM," n.d.

- - . "The IMPLEMENTASI NILAI-NILAI MULTIKULTURALISME MELALUI PEMBELAJARAN PENDIDIKAN AGAMA ISLAM (THE IMPLEMENTATION OF MULTICULTURALISM VALUES THROUGH LEARNING OF ISLAMIC RELIGION EDUCATION)." Risâlah, Jurnal Pendidikan Dan Studi Islam 5, no. 1 (2019): 1-18.

- - . "Urgensi Inovasi Pembelajaran Islam Dalam PAI." Al-Afkar, Journal for Islamic Studies 2, no. 1 (2019): 64-86. https://doi.org/10.5281/zenodo.3553865.

Rosyad, Ali Miftakhu, and Muhammad Anas Maarif. "PARADIGMA PENDIDIKAN DEMOKRASI DAN PENDIDIKAN ISLAM DALAM MENGHADAPI TANTANGAN GLOBALISASI DI INDONESIA.” Nazhruna: Jurnal Pendidikan Islam 3, no. 1 (2020): 75-99.

Rozalinda, Ekonomi Islam. "Teori Dan Aplikasinya Pada Aktivitas Ekonomi Jakarta.” Rajawali Press, 2016.

Syathori, Ahmad. "KONSEP WELFARE-ECONOMIC: ANTARA ETIKA BISNIS ISLAM DAN PROTESTAN.” Risâlah, Jurnal Pendidikan Dan Studi Islam 3, no. 1 (2016): 78-93.

Wibowo, Adi. "Tinjauan Hukum Islam Terhadap Praktik Pinjammeminjam Uang Di Desa Nglorog Kec. Sragen Kab. Sragen.” Skripsi--UIN Sunan Kalijaga, Yogyakarta, 2013. 
Yulianti, Rahmani Timorita. "Transparansi Anggaran: Suatu Upaya Efisiensi Dan Antisipasi Korupsi Di Indonesia." La_Riba: Jurnal Ekonomi Islam 4, no. 2 (2010): 239-50.

Adi Nugroho Setiarso, Analisis Yuridis terhadap Keadaan Insolvensi Dalam Kepailitan(Study Normatif Pasal 2 Ayat (1) Undang-Undang Nomor 37 Tahun 2004 Tentang Kepailitan dan Penundaan Kewajiban Pembayaran Utang), Artikel Ilmiah, Kementrian Pendidikan dan kebudayaan Fakultas Hukum Universitas Brawijaya, Malang, 2013.

Catur Indiro, Penerapan Asas Kelangsungan Usaha dalam Penyelesaian Perkara Kepailitan dan Penundaan Kewajiban Pembayaran Utang (PKPU), Jurnal hukum peradilan, vol.4 No.3. Pekanbaru. 7.

Khoiri, Syamsul, "Peraturan Hukum Perburuhan Dan Sikap Pengadilan: TarikMenarik Antara Kepentingan Investor Dan Kepentingan Buruh”, Jurnal Hukum \& Pembangunan, Tahun ke-39 No.3 Juli-September 2009.

Munif Rochmawanto, "Upaya Hukum Dalam Perkara Kepailitan”.Jurnal Independen. Vol.3 No. 2, hal 25.

Suryani H, Any, "Pengaturan Perlindungan Hukum Bagi Tenaga Kerja Wanita Beserta Keluarganya Berdasarkan Uu No. 6 Tahun 2012 Tentang Pengesahan Konvensi Internasional Perlindungan Buruh Migran Beserta Keluarganya", Jurnal Hukum \& Pembangunan, Vol. 46, No. 2, 2016.

Indonesia. Undang-Undang Nomor 13 Tahun 2003 tentang Ketenagakerjaan Indonesia. Undang-Undang Nomor 2 Tahun 2004 tentang Penyelesaian Persselisihan Hubungan Industrial.

Indonesia. Undang-Undang Nomor 37 Tahun 2004 tentang Kepailitan dan PenundaanKewajiban Pembayaran Utang.

Indonesia. Undang-Undang Nomor 40 Tahun 2007 tentang Perseroan Terbatas.

Kementerian Tenaga Kerja RI. Peraturan Menteri Tenaga Kerja Nomor 33 Tahunzo16 tentang Tata Cara Pengawasan 